\title{
DAVID WEBSTER, 1945-89: A CAMPAIGNER FOR HUMAN RIGHTS
}

\section{Barbara Klugman writes:}

David Webster, a social anthropologist, anti-apartheid activist and humanist, was assassinated outside his home in Johannesburg, South Africa, on 1 May 1989. Hundreds of thousands of South Africans heard of his death with shock and horror; thousands of South Africans knew him personally as a teacher, comrade, friend, colleague or fieldworker. Thousands came to his funeral and buried him with the ritual befitting an anthropologist who gave his life for the people and the future of his country.

David was an exemplary human being, gentle and kind, fun-loving, generous to a fault, a symbol of unity, a symbol of integrity. Whether as a fieldworker in KwaZulu, a teacher at the University of the Witwatersrand, or an activist in the anti-repression movement, David brought these qualities with him; they integrated the vast range of his activities, attracted people of all ages and walks of life to him, and made them his friends.

David Webster was born in 1945 in Luanshya on the Zambian Copperbelt, where he went to junior school. He completed high school in Zimbabwe, and studied anthropology at the University of Rhodes. He then embarked on fieldwork among the Chopi of Inharrime, Mozambique. Here he did a community study which formed the basis of his $\mathrm{PhD}$. In 1971 he was employed as a lecturer at the University of the Witwatersrand, and in 1976 was invited to do a locum at Manchester University.

The remarkable quality which David brought to his academic work was his ability to fuse academic interest with his broader social interest. So at the same time as David took on a study of unemployment and informal sector activity in Soweto, he immersed himself in Sowetan culture: he got to know the local musicians, and he collected written and oral histories on the development of their music; he was so enthusiastic in this that he was on occasion asked to judge local musical competitions, which he did with a mixture of embarrassment and delight. He also became a fervent follower of the Orlando Pirates soccer team. David's interest in migrancy, which developed while doing fieldwork in Mozambique, translated itself in Johannesburg into 'social history tcurs' of Johannesburg. David offered interested people bus or bicycle tours of the early mining compounds and townships. He also began to teach an anthropology of labour course, once again returning to the academic realm to integrate this material.

During this time David's exploration of the Marxist paradigm led him to offer courses on reproduction, moving from the most abstract of theory to practical investigations of the problems of reproduction in South Africa, focusing on housing, health and education. This occurred in a context in which, in the absence of many academics actively engaged in the anti-apartheid struggle, David was repeatedly called upon to talk at student conferences and protest meetings about the issues of the day. As a result he produced a large number of papers on these themes. David's courses offered students a means of coming to grips with the stark contradictions of South African reality. Many of today's activists took their first step into social responsibility after passing through David's classes.

In 1981, Barbara Hogan, a postgraduate student of David's, was detained under security legislation and later sentenced to ten years' imprisonment for high treason. Neil Aggett, another detainee, died in detention. These events marked a turning point in David's life. Alongside parents and friends of detainees, David threw all his energy, skills and human kindness into campaigning against detention without trial, and into improving the lot of detainees. With the declaration of a state of emergency in 1985 
and the subsequent detention of over 20,000 people, David's work became allconsuming.

Two aspects of his contribution stand out above all else. The first is his humanity, the second the way that he brought his academic skills to bear on the crisis. With reference to the first, Mohammed Valli Moosa, acting general secretary of the United Democratic Front, said at David's funeral that the tracksuits, running shoes and Christmas parcels that David painstakingly arranged for every detainee kept up their morale in the most frightening and lonely of circumstances.

With regard to the second, David's methodical approach to information and his years of analytical training contributed to the success of the international campaign against repression in South Africa. In both 1985 and 1986 he gave evidence to the United Nations Commission on Human Rights. In his latest article on repression, written with his fiancée Maggie Friedman, he macabrely notes that, 'Assassinations have the effect of controlling government opposition when all other methods, such as detention or intimidation, have failed. It is very rare that such assassinations are solved' (1989: 30).

In 1986 David returned to fieldwork, in Kwa Dapha, KwaZulu. Amos Ngubane, David's friend and field assistant, describes how, when David first set up home in the bush, people thought he was 'mad' and felt sorry for him. But slowly, as he worked with them in their fields, and participated in community meetings, they came to love and admire him. Amos describes how David offered his car as a hearse; how he helped in organising schooling for people's children; how he braved the bureaucracy to ensure that pensioners got their due. On David's death the community held a ritual service and feast, and thus bade him farewell as if they had lost one of their own.

\section{REFERENCE}

Webster, David, and Friedman, Maggie, 1989. Repression and the State of Emergency Fune 1987-March 1989. Johannesburg: Southern African Research Service and Ravan Press. 